\title{
Influence of Processing on Protein Quality
}

\author{
Jean MAURON \\ University of Fribourg, Fribourg, Switzerland
}

Summary In the first part the reactions and interactions of protein with macroconstituents of our food during processing are exposed from the chemical point of view. The reactions involving only protein (formation of isopeptides, of lysinoalanine, racemization) and the interactions with carbohydrates (Maillard reaction), oxidized lipids and polyphenols are briefly presented. Emphasis is put on the Maillard reaction since it is the most frequent reaction occurring during food processing and storage. The key compound rendering lysine unavailable in processed and stored foodstuffs is $N^{\varepsilon}$-fructoselysine (FL). Its oxidative degradation product, $N^{\varepsilon}$-carboxymethyllysine (CML) is found in variable but significant amounts in heat processed proteins. An interesting newer finding is that tryptophan can participate in a Maillard reaction with its indole-NHgroup.

In the second part an overview is given on the impact these reactions have on the two components of protein nutritive value, namely digestibility and biological value. Again, most examples will be related to the Maillard reaction. Protein digestibility may be reduced by the modification of the protein molecule (blocking of active amino acid side-chains, establishment of crosslinks) or by the formation of compounds that inhibit digestive enzymes. (Inhibition of aminopeptidase by an advanced Maillard derivative of lysine). Biological value may be diminished by the loss of essential amino acids and/or their reduced specific availability. Ion-exchange chromatography of the protein hydrolyzate is the method of choice to determine amino acid losses. It also provides some clues for the type of processing damage by the presence of unusual amino acids in the chromatogramme (e.g. furosine, lysinoalanine). Global amino acid bioavailability is defined. It is of a complex nature and can only be truely determined in a bioassay in the animal. Specific availability of an amino acid is linked to particular structural features. Thus, specific lysine availability is determined by the presence of a free or "reactive" $\varepsilon$-amino group. This is the basis for the analytical methods for available lysine.

In the third part, the practical application of this knowledge to processed foods is shown using milk and vegetable protein as examples. Figures for the reduction in available lysine (blocked lysine) in different milk products processed according to conventional procedures are given and discussed. More subtile effects of milk processing on milk digestibility 
and stomach emptying are mentioned. The effects on protein nutritional value of extrusion-cooking of legume seeds and cereal flours are, then, presented. Whereas sulphur amino acid bioavailability and protein digestibility in legumes are improved by appropriate extrusion-cooking, extensive lysine loss and nutritional damage can take place when cereal flours are extruded under severe conditions.

It is concluded that, nowadays, extensive knowledge of the reaction mechanisms, appropriate analytical methods and flexible processing operations are available to prevent to a large extent protein nutritional losses.

Key Words protein quality, processing, lysine, methionine, tryptophan, Maillard reaction, oxidizing lipids, isopeptides, lysinoalanine, fructoselysine, amino acid availability, milk, extrusion-cooking, vegetable proteins.

The mechanisms leading to changes in protein quality can be reduced to a few fundamental interactions. Their impact on protein nutritive value will be discussed and some practical aspects presented.

\section{A. CHEMISTRY OF THE MAIN INTERACTIONS}

\section{Protein reactions}

a) Racemization. Alkaline treatments $(\mathrm{pH} \mathrm{8-12)}$ are often an unavoidable part of the processing operations for vegetable proteins. These treatments can lead to racemization (1). Severe heating alone can also result in racemization but only aspartic acid is involved in this case $(1)$. Alkaline treatment $\left(\mathrm{pH} 12,90^{\circ} \mathrm{C}, 2 \mathrm{~h}\right)$ of Vicia faba protein isolate leads to important racemization of phenylalanine $(45 \%)$ and threonine/serine (79\%) whereas leucine, isoleucine and methionine are stable (2). Under careful processing conditions, however, racemization is negligible and involves aspartic acid only. New alkaline treatments should always be checked for their possible effect on racemization.

b) Lysinoalanine formation. Lysinoalanine (LAL) can be formed in proteins by reaction of lysine with dehydroalanine produced by a $\beta$-elimination from cysteine and serine. It can be formed during alkaline treatments of protein-containing foods but can also be present in heated foodstuffs, including milk products (3). Spray-dried milk powders contain no or only traces of LAL, conventional in-can sterilized milk significant amounts (below $0.1 \%$ of the protein), that represent, however, less than $1 \%$ of the lysine present in milk protein. LAL formation in food proteins has been reviewed by Finot (4). Phenylethylamine can react like lysine with dehydralanine residues to form [(Phenyl-ethyl)amino]alanine (PEAA) in food (5) (Fig. 1).

c) Lysinomethylalanine (LMeAL) formation. Recently, it could be shown (6) that upon heating of threonine- and lysine-containing tripeptides under alkaline conditions LMeAL is formed. The mechanisms is analogous to the LAL formation. 


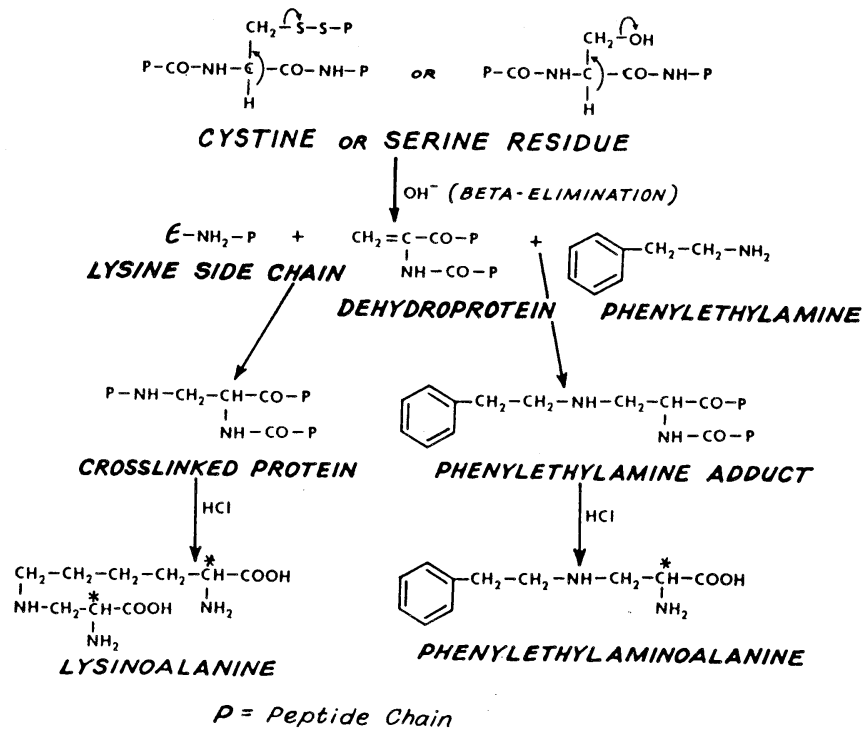

Fig. 1. Transformation of cystine and serine residues in a protein to lysinoalanine and [(phenylethyl)amino]alanine. Newly created asymmetric centers are indicated by asterisks.

By $\beta$-elimination threonine yields 3-methyldehydroalanine which reacts with the $\varepsilon$-amino group of lysine to form LMeAL. The extent of this new reaction in alkaline processed proteins has not yet been investigated.

d) Formation of isopeptides. Relative severe heating of proteins in concentrated form (muscle meat, soya, etc.) can lead to the formation of internal peptide links between the $\varepsilon$-amino group of lysine and amide groups in the protein (asparagine, glutamine) (7). The isopeptides $\varepsilon$ - $(\gamma$-glutamyl)-lysine and $\varepsilon$-( $\beta$-aspartyl)lysine corresponding to these new links have been synthesized ( 8 ).

\section{Protein-carbohydrate interactions}

The reaction of proteins with reducing sugars, the so-called Maillard reaction, is the major source of flavour and of nutritional damage during the culinary and industrial preparation of food. It has been extensively studied and reviewed (9).

a) Early Maillard reactions. The first step is a simple condensation reaction between the carbonyl group of a reducing carbohydrate and the free amino groups of a protein, peptide or amino acid. The condensation product rapidly looses a molecule of water to form the Schiff base, which undergoes cyclization to the corresponding $N$-substituted glycosylamine. Up to this point, the reaction is reversible. The key step in the early Maillard reaction is the "Amadori" rearrangement in which the aldose (glucosylamine) is transformed into a ketose, namely the 1-amino-1-deoxy-2-ketose. This reaction is irreversible and the "Amadori" compound formed is relatively stable. In food proteins, the main reactive 


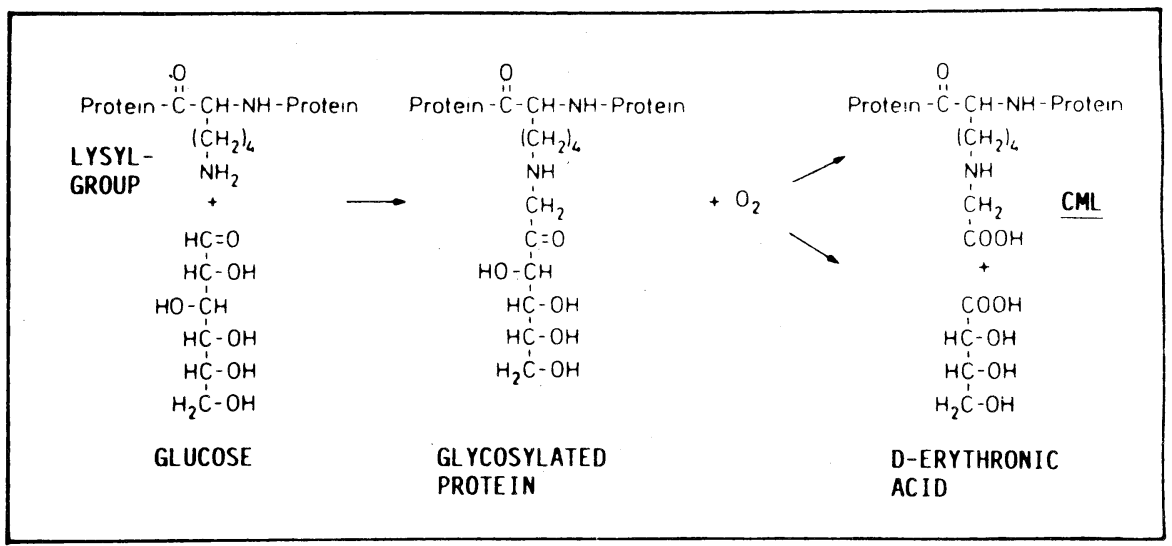

Fig. 2. Formation of carboxymethyllysine (CML).

amino group is the $\varepsilon$-amino group of lysine. When the sugar is glucose, the main "Amadori" compound in a heated protein is, therefore, $\varepsilon-N$-deoxyfructosyl-L-lysine or, simpler, $N^{\varepsilon}$-fructoselysine (FL) in a bound form. In milk, the corresponding "Amadori" compound formed is $N^{\varepsilon}$-lactuloselysine (LL) (9). Fructoselysine (FL) can undergo oxidative decomposition under mild conditions $\left(37^{\circ} \mathrm{C}\right.$, air, $\left.\mathrm{pH} 7.4\right)$ to form $N^{\varepsilon}$-carboxymethyllysine (CML) (Fig. 2) (10). Preliminary results obtained by Badoud(11) suggest that quantitative oxidation of $\mathrm{FL}$ with periodate and determination of CML by HPLC could be used to measure FL in heated foodstuffs.

Tryptophan can also undergo an early Maillard reaction with its indole-NH group and reducing sugars, but only at acidic $\mathrm{pH}$ (acetic acid)(12). Thus, $N^{\alpha}$-acetyl-1-( $\beta$-D-glucopyranosyl)-DL-tryptophan amide (Fig. 3) was generated through condensaion reaction between $N^{\alpha}$-acetyl-DL-tryptophan amide and D-glucose. This may be considered a $N$-substituted glycosylamine. Whether this reaction occurs in processed foods is not yet known. It could be of some importance in tinned foodstuffs with low $\mathrm{pH}$ values.

The sulphur amino acids cystine and methionine are not involved in the early Maillard reaction (13).

b) Advanced Maillard reactions. Under more severe heating or storage conditions, the Maillard reaction proceeds further to the different advanced steps. These reactions lead to the formation of literally thousands of compounds which are responsible for the numerous flavours and odours of heated foods (9). As regards essential amino acids, a few remarks should be made.

Lysine heated with glucose $\left(6 \mathrm{~h}\right.$ at $\left.105^{\circ} \mathrm{C}\right)$ forms $\varepsilon$-(2-formyl 5-hydroxymethylpyrrol-1-yl)-L-norleucine ( $\varepsilon$-pyrrole-lysine, PL) (14), an advanced Maillard product of lysine (Fig. 4).

Tryptophan can react with its indole-NH group with active carbonyl intermediates formed during the advanced Maillard reaction (15). Reaction products 


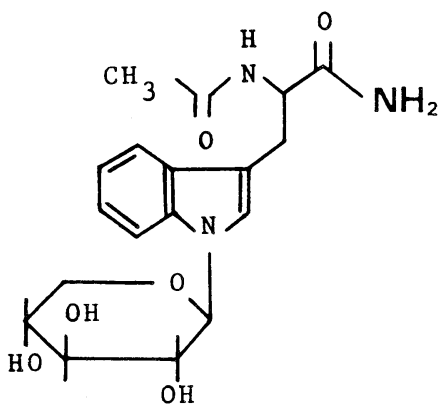

Fig. 3. $\quad N^{\alpha}$-acetyl-I-( $\beta$-D-glycopyranosyl)DL-tryptophanamide.
(1)

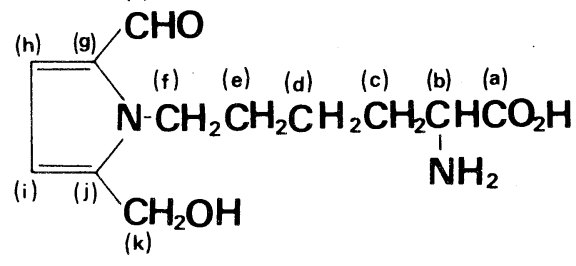

Fig. 4. $\varepsilon$-Pyrrole-lysine.<smiles>CC(=O)NC(Cc1cn(C(O)C(=O)CC(O)C(O)CO)c2ccccc12)C(=O)O</smiles>

Fig. 5. A proposed structure for Trp-3DG-1.

between $N^{\alpha}$-acetyl-tryptophan and glyoxal, methylglyoxal and 3-deoxyglucosone have been identified. A proposed structure for the reaction product of acetyl-tryptophan and 3-deoxy-glucosone is given (Trp-3DG-1) (Fig. 5). Whether tryptophan residues in an intact food protein react in a similar way is not clear.

At last it should be mentioned that cystine is not affected by the advanced Maillard reaction, whereas methionine is progressively destroyed by an unknown mechanism(13). The later stage of the advanced Maillar reaction results in the formation of a great number of heterocyclic compounds involving oxygen, nitrogen and sulphur (9) resulting in the destruction of the amino acids.

c) Final Maillard reactions. The final phase produces the brown melanoidin pigments, that result from the polymerization of the many highly reactive compounds formed during the advanced Maillard reactions.

The course of the Maillard reaction is strongly influenced by temperature, duration, water activity and $\mathrm{pH}$. It is slowed down by very high and very low water activity in the food and by lowering the $\mathrm{pH}$. 


\section{Protein-oxidized lipid interactions}

The oxidation of unsaturated lipids proceeds in three steps, i.e. the formation of a) primary products (hydroperoxides); b) secondary products (aldehydes, ketones, etc.); c) stable compounds (carboxylic acids and polymerization products). a) and b) may react with protein and modify some amino acids. Using a model reaction (whey protein incubated with methyllinolenate under varying conditions of temperature, water activity and oxygen tension), Nielsen $(16,17)$ showed that three essential amino acids were affected. Methionine reacted most rapidly, followed by lysine and, later, tryptophan. Methionine is oxidized by the hydroperoxides (a) to its sulphoxide, lysine reacts with the carbonyls (b) in a Maillard-type reaction and tryptophan also with the carbonyls (b) at its nitrogen of the indole ring. At high water activity (0.84), excess oxygen ( $4 \mathrm{~mol}$ per mol lipid) and high temperature $\left(55^{\circ} \mathrm{C}\right.$ ) about $90 \%$ of methionine, $60 \%$ of lysine and $20 \%$ of tryptophan had reacted in 7 days.

\section{Protein-polyphenol interactions}

In modern plant processing, protein extraction with alkali is a frequent operation during which browning reaction with polyphenols can occur. The quinones (oxidation products of polyphenols) can react with the $\varepsilon$-amino group of lysine (18) leading to the formation of covalent lysine-quinone complexes. The quinones can also react with methionine which is oxidized to its sulphoxide.

\section{Pyrolysis}

Heating foods at temperatures above $300^{\circ} \mathrm{C}$ leads to so-called pyrolysis reactions, which are quite different from the classic Maillard reaction as shown by the pyrolysis compounds formed from pure proteins, peptides and amino acids in the total absence of carbohydrates. Pyrolysis compounds are often mutagenic.

\section{B. IMPACT ON PROTEIN NUTRITIVE VALUE (18) (Table 1)}

\section{Protein digestibility}

a) Intrinsic digestibility. Heat processing of food will influence protein digestibility in at least four ways. First, by modifying the tertiary and secondary structure ("denaturation") of the protein, heat will, generally, increase protein digestibility. This effect is most pronounced for certain vegetable proteins such as legume seed protein, soya protein being the best known sample (19). Second, amino acid side-chains may be modified, impeding the action of certain digestive enzymes. Thus, the blocking of the $\varepsilon$-amino group of lysine in heated milk will hinder the action of trypsin and reduce global protein digestibility (20). Third, new cross-links may be formed within or between molecules (isopeptides, disulfide bridges, aldol condensation, malonaldehyde links, polyphenol complexes) that reduce the digestibility of the whole protein molecule or of certain fragments of the molecule. Active intermediates of the advanced Maillard reaction (dicarbonyls, aldehydes) 
Table 1. Protein nutritive value.

\begin{tabular}{|c|c|c|c|c|c|}
\hline \multirow{2}{*}{ Interactions } & \multirow{2}{*}{$\begin{array}{c}\text { True } \\
\text { digestibility }\end{array}$} & \multicolumn{4}{|c|}{ Biological value } \\
\hline & & $\begin{array}{l}\text { Amino acid } \\
\text { destruction }\end{array}$ & $\begin{array}{l}\text { Unavailable } \\
\text { peptides }\end{array}$ & $\begin{array}{r}\text { Spe } \\
\text { avail }\end{array}$ & $\begin{array}{l}\text { cific } \\
\text { ability }\end{array}$ \\
\hline \multicolumn{6}{|l|}{ Protein Interactions } \\
\hline Isopeptides & -- & 0 & $\begin{array}{c}++ \\
+\end{array}$ & $\begin{array}{l}\text { Lys-Glu } \\
\text { Lys-Asp }\end{array}$ & $\begin{array}{l}\text { normal } \\
0\end{array}$ \\
\hline D-amino acids & -- & 0 & & variable & \\
\hline Lysinoalanine & - & ++ & 0 & Lys - - & $(=$ destr $)$ \\
\hline $\begin{array}{l}\text { Early Maillard } \\
\text { Reaction }\end{array}$ & - & Lys + Try +? & 0 & $\begin{array}{l}\text { Lys }-- \\
\text { Try }-?\end{array}$ & $(>$ destr. $)$ \\
\hline $\begin{array}{l}\text { Advanced Maillard } \\
\text { Reactions }\end{array}$ & -- & $\begin{array}{l}\text { Lys }+++ \\
\text { Met }+ \\
\text { Try }+ \text { ? }\end{array}$ & + & $\begin{array}{l}\text { Lys - - - } \\
\text { Met - } \\
\text { Try -? }\end{array}$ & $\begin{array}{l}(=\text { destr. }) \\
(=\text { destr. })\end{array}$ \\
\hline $\begin{array}{l}\text { Protein-oxidized } \\
\text { Lipid }\end{array}$ & -- & $\begin{array}{l}\text { Lys }++ \\
\text { Met }+++ \\
\text { Try } 0+\end{array}$ & $+?$ & $\begin{array}{l}\text { Lys - - - } \\
\text { Met - } \\
\text { Try normal }\end{array}$ & $\begin{array}{l}(>\text { destr. }) \\
)<\text { destr. }) \\
\text { or }-\end{array}$ \\
\hline Protein-polyphenol & -- & $\begin{array}{l}\text { Lys }+ \\
\text { Met }+ \\
\text { Try } 0\end{array}$ & ++ & $\begin{array}{l}\text { Lys - - } \\
\text { Met - } \\
\text { Try }\end{array}$ & $\begin{array}{l}(>\text { destr. }) \\
(<\text { destr. }) \\
\text { normal }\end{array}$ \\
\hline
\end{tabular}

$-=$ decreased,$+=$ present,$+=$ present,$-=$ drop, $>=$ drop bigger than destr., $<=$ drop smaller than destr.

may act as bridge between amino acid side chains. This could explain the global reduction in digestibility (and bioavailability) of all amino acids in proteins that have undergone an advanced Maillard reaction(13). In a similar way, the secondary products of lipid oxidation (e.g. malonaldehyde) can form enzyme-resistant cross-links. The very big fall in protein digestibility observed by Nielsen (16) in some protein-oxidized lipid interaction products can be explained in this way. Forth, racemization will hamper the hydrolysis of peptide bounds involving D-amino acids.

b) Inhibition of digestive enzymes. A number of heterocyclic compounds formed in the later steps of the advanced Maillard reaction are strong inhibitors of carboxypeptidase $\mathrm{A}(21)$. Two are also competitive inhibitors of amino peptidase $\mathrm{N}$, the most effective being $\varepsilon$-pyrrole-lysine (PL) (21).

\section{Protein biological value}

a) Loss of essential amino acids. The most obvious effect of many processing operations is the loss of amino acids, i.e. the destruction of their carbon skeleton. The method of choice for the determination of amino acid losses is the measurement of the amino acid content in the food before and after processing. This is best done by ion-exchange chromatography of the acid hydrolysate(22). In addition, inspection of the chromatogram allows to detect some types of processing damage; lysinoalanine and ornithinoalanine being typical for alkaline treatments, furosine 
and pyridosine for early Maillard damage. (Trivial names I gave to two hydrolysis products of FL) (9).

The impact the different types of interactions have on amino acid losses are quite dissimilar. Racemization and the formation of isopeptides cause no amino acid losses. Lysinoalanine (LAL) formation gives rise to losses in lysine and cysteine $(+$ serine). However, the amount of amino acids involved in this reaction in regular food processing, including alkaline treatments, is so small that amino acid losses are negligible. LAL formation may, however, represent a toxicological problem. The early Maillard damage causes lysine losses that are of a complex nature. Indeed, a protein in which lysine has undergone a complete early Maillard damage by the formation of fructoselysine (FL) will generate furosine (32\%) and regenerate lysine $(40 \%)$ upon acid hydrolysis (23). Consequently, the lysine loss measured by comparing total lysine in the hydrolysate of the damaged sample with that in the undamaged will amount to $60 \%$ instead of $100 \%$.

Advanced and final Maillard reactions destroy the amino acids involved. Protein-oxidized lipids reactions lead to losses in lysine, methionine, cystine and tryptophan. Part of the lysine in such reaction products is also present in a regenerable form (upon acid hydrolysis), behaves therefore like FL. Proteinpolyphenol interactions lead to the loss of methionine (methionine sulphoxide) and lysine but not tryptophan (18). Again, part of the lysine is present in a regenerable form. Pyrolysis causes the destruction of the amino acids.

b) Amino acid availability. Global amino acid bioavailability has been defined as the amount or percentage of a given amino acid in the food which is utilized for protein synthesis in the organism (growth or maintenance), when this amino acid is the only limiting factor of the diet (24). Bioavailability will, therefore, depend on protein digestibility, on amino acid absorption and on intracellular amino acid utilization. It is thus of a complex nature. It can only be determined in vivo in a bioassay on the whole animal who is fed a basal diet limiting in the essential amino acid to be tested. One component of amino acid availability, i.e. protein digestibility (true $N$ digestibility) was already discussed. The latter does not always reflect the absorption of particular amino acids, since new cross-links may hamper the digestion of certain fragments of the protein rich in that particular amino acid. On the other hand, some peptides may be absorbed from the gut and excreted in the urine (not utilized)(9). These components of availability can only be studied by radiobioassay (25). Another factor influencing availability is the so-called amino acid inactivation, i.e. the modification of an amino acid side-chain changing its metabolic behaviour. This structural change is specific for a given amino acid and can be considered the specific component of bioavailability (specific availability). For two essential amino acids such a specific availability can be defined in chemical terms. The methionine side-chain can be oxidized to the sulphoxide, a form that is slightly less available than methionine (83-96\% in the rat (16); 62\% in chicks (26). For lysine the situation is more clear-cut. In order to be available, lysine must have a free or "reactive" $\varepsilon$-amino group. The direct-FDNB (fluorodinitrobenzene) (9) 
and the guanidination (9) procedures take advantage of this fact to measure quantitatively specific lysine availability in processed foods.

A few remarks should be made here on the influence of the different interactions on amino acid bioavailability. The formation of isopeptides may reduce the specific availability of lysine. It is interesting to note that the free isopeptide $\varepsilon$-(-glutamyl)-L-lysine is fully available as source of lysine for both rats and chicks (8), but that the free $\varepsilon$-( $\beta$-aspartyl)-L-lysine is not. Some D-forms of amino acids are available (e.g. tryptophan) others are not (e.g. lysine)(27). LAL is unavailable as source of lysine. The same is true of FL (28), which is the exclusive form of inactivated (blocked) lysine in moderately heat processed milk. Upon acid hydrolysis FL yields furosine that can be used to determine the percentage of lysine rendered unavailable (=blocked) in milk products using the formula

$$
\% \text { blocked lysine }=\frac{3.1 \text { furosine } \times 100}{\text { total lysine }+1.87 \text { furosine }} .
$$

In protein-oxidized lipid interactions, specific lysine availability is reduced to a certain extent due to amino-carbonyl reactions involving the $\varepsilon$-amino group. Specific methionine availability is only very little affected because methionine sulphoxide is almost completely available. There is no reduction in specific tryptophan availability, the result of the bioassay with tryptophan on the rat can be fully explained by tryptophan destruction and reduced global protein digestibility.

Protein-polyphenol interactions cause a drop in specific lysine availability through the formation of lysine-quinone complexes that are not absorbed (18). Specific methionine availability is very slightly reduced (methionine sulphoxide). Specific availability of tryptophan is not influenced nor is this amino acid destroyed. Global tryptophan bioavailability is, however, diminished because of reduced protein digestibility.

\section{PRACTICAL APPLICATIONS}

Two examples are given: milk protein and vegetable protein, the former because it is often the sole food for infants, the latter because the most abundant sources are found in raw material that needs heat processing.

\section{Milk}

a) Lysine damage in commercial milk samples. Since in heated milk (normal industrial processing) heat damage is almost exclusively of the early Maillard type, the determination of blocked lysine is the best tool for the evaluation of processing damage. Table 2 shows the range of values found in milk preserves prepared according to good manufacturing practice. Pasteurization and spray-drying of milk does barely damage lysine, whereas in-can sterilization always blocks some lysine. It should be noted, however, that special milk formulas rich in lactose or glucose are more prone to an early Maillard damage. Even spray-dring, when not properly 
Table 2. Lysine damage in commercial milk samples.

\begin{tabular}{lc}
\hline \multicolumn{1}{c}{ Samples } & $\%$ blocked lysine \\
\cline { 2 - 2 } Pasteurized milk & 0 \\
Sterilized fluid milk (conventional) & $10-15$ \\
Spray-dried milk powder & $0-2$ \\
Spray-dried infant formulas & $2-10$ \\
Sweetened condensed milk & $0-2$ \\
Evaporated milk & $15-20$ \\
Roller-dried milk powder & $20-30$ \\
Spray dried lactose-hydrolysed milk powder & $15-60$ \\
\hline
\end{tabular}

handled, can cause considerable lysine blockage in these cases.

b) Special metabolic effects. In recent times, special metabolic effects of ingested food are more and more considered as an aspect of nutritional quality that should not be neglected. Thus, the classic notion of true digestibility takes into account only the final result of the digestive process, but neglects the gastro-intestinal transit time, which influences the appearance of the nutrients in the bloodstream.

Milk is an interesting example of a food, the transit time of which can be modulated by technological processes. Casein coagulates in the stomach in more or less solid form according to the milk processing, and influences thus stomach emptying time. Assays performed on the minipig have shown that gastric transit time is clearly delayed with raw and pasteurized milk, whereas the intake of ultra-high-temperature (UHT) pasteurized milk leads to a rapid stomach emptying. The appearance of amino acids and urea in the blood follows a similar pattern, it is delayed with raw milk and accelerated with UHT milk (29) (Fig. 6).

Another aspect is the liberation of $\beta$-casomorphin-11 from casein, which also delays gastric transit and activates the liberation of insuline and somatostatin (30). More attention should be given in the future to the impact of processing on such metabolic aspects, and the concept of protein quality would have to be enlarged.

\section{Vegetable protein (extrusion-cooking)}

a) Improvement of nutritive value. A good example of improvement of nutritive value by processing is provided by extrusion-cooking of soyabeans and many other legume- or oil-seeds. Thermal inactivation of trypsin inhibitors and other growth-retarding factors and thermal unfolding of the major seed globulins improve protein digestibility and bioavailability of the limiting sulphur amino acids $(31)$.

b) Losses in protein nutritional value(32). Losses during extrusion-cooking are not only linked to the presence of reducing sugars but also of starch. Cereals are, therefore, more prone to damage than legume seeds. The damage is, generally, of the Maillard type as shown by the loss of lysine, and is enhanced by low moisture content. Starch is partly dextrinized by severe extrusion conditions thus providing reducing carbohydrates (33). 


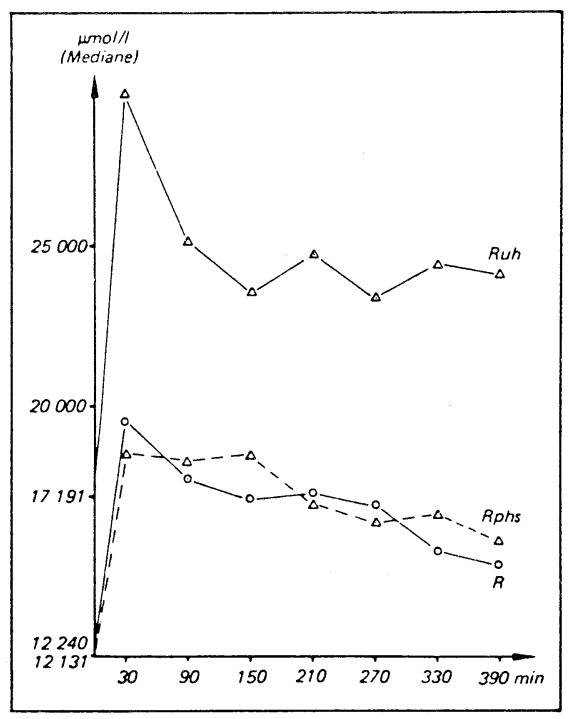

Fig. 6. Amino acid concentration in blood serum after feeding of 1 liter milk. $\mathrm{R}=$ raw milk, Ruh =sterilized milk (ultra-high-temperature), Rphs=pasteurized, homogenized, fermented milk.

The impact of extrusion-cooking on wheat flour and on whole-grain wheat flour was studied by Björck et al.(34). In wheat flour, the lysine loss ranged from $0-37 \%$ depending on processing conditions. No losses occurred in other amino acids. The highest loss was observed at the highest mass temperature. The amino acid composition of the whole grain wheat flour was almost unaffected by processing ( $9 \%$ lysine lost at the most severe processing conditions).

True digestibility (TD) was not affected in wheat flour, even under severe conditions. In contrast, with whole-grain flour, there was a decrease in TD $(6 \%)$ during processing.

The biological value (BV) of wheat flour processed under mild conditions was similar to that of raw flour, whereas the BV of the more severely processed wheat flour was reduced. In the whole-grain product, there was also a decrease in BV.

The lower lysine loss in the whole-grain flours is probably due to a higher moisture content of the feed. The decrease in TD in the whole grain product may be due to interactions between digestible polysaccharides and protein. In order to obtain high quality wheat products, the extrusion conditions must be carefully selected and adapted to the type of wheat flour. Under severe processing conditions, high lysine losses occurr.

\section{CONCLUSION}

Nowadays, extensive knowledge of the reaction mechanisms, appropriate Vol. 36, Suppl. I, 1990 
analytical and biological methods and flexible processing operations are available to prevent, to a large extent, protein nutritional losses. The proper use of this knowledge needs, however, sound judgement and discrimination as well as cost benefit considerations. Protein quality does not have the same importance for a snack food occasionally eaten by affluent people whose protein intake is already high as for a staple, like milk, which is the main protein source for an infant.

\section{REFERENCES}

1) Liardon, R., and Hurrell, R. F. (1983): Amino acid racemization in heated and alkali-treated proteins. J. Agric. Food Chem., 31, 432-437.

2) Krause, W., and Freimuth, U. (1985): Zur Alkalibehandlung von Proteinen. 7. Mitt. Racemisierung und enzymatische Hydrolyse. Die Nahrung, 29, 957-968.

3) Fritsch, R. J., and Klostermeyer, H. (1981): Bestandesaufnahme zum Vorkommen von Lysinoalanin in milcheiweisshaltigen Lebensmitteln. Z. Lebensm. Unters. Forsch., 172, 440-445.

4) Finot, P. A. (1983): Lysinoalanine in food proteins. Nutr. Abstr. Rev. Clin. Nutr., A53, 67-80.

5) Friedman, M., and Noma, A. T. (1986): Formation and analysis of [(phenylethyl)amino]alanine in food proteins. J. Agric. Food Chem., 34, 497-502.

6) Kruse, B., and Steinhart, H. (1989): Evidence for lysinomethylalanine formation in model systems. J. Agric. Food Chem., 37, 304-307.

7) Bjarnason, J., and Carpenter, K. J. (1970): Mechanisms of heat damage in proteins. Br. J. Nutr., 24, 313-329.

8) Finot, P. A., Mottu, F., Bujard, E., and Mauron, J. (1978): $N$-substituted lysines as sources of lysine in nutrition, in Nutritional Improvement of Food and Feed Proteins, ed. by Friedman, M., Plenum Press, New York, pp. 549-570.

9) Mauron, J. (1981): The Maillard reaction in food: a critical review from the nutritional standpoint, in Progress in Food and Nutrition Science, Vol. 5: Maillard Reactions in Food, ed. by Eriksson, C., Pergamon Press, Oxford, pp. 5-35.

10) Büser, W., Erbersdobler, H. F., and Liardon, R. (1987): Identification and determination of $N$ - $\varepsilon$-carboxymethyllysine by gas-liquid chromatography. J. Chromatogr., 387, 515-519.

11) Badoud, R. (1989): Oxidative degradation of protein-bound Amadori products: Formation of $N$ - $\varepsilon$-carboxymethyllysine, a useful indicator of the extent of non-enzymatic glycosylation. 4th Internatl. Symposium on the Maillard Reaction, Sept. 5-8, Lausanne, Switzerland.

12) Nyhammer, T., and Pernemalm, P. A. (1985): Reaction of $N^{\alpha}$-acetyl-DL-tryptophan amide with D-xylose or D-glucose in acidic solution. Food Chem., 17, 289-296.

13) Hurrell, R. F., Finot, P. A., and Ford, J. E. (1983): Storage of milk powders under adverse conditions. I. Losses of lysine and other essential amino acids. Br. J. Nutr., 49, 343-354.

14) Nakayama, T., Hayase, F., and Kato, H. (1980): Formation of $\varepsilon$-(2-formyl-5-hydroxymethyl-pyrrol-1-yl)-L-norleucine in the Maillard reaction between D-glucose and L-lysine. Agric. Biol. Chem., 44, 1201-1202.

15) Saito, G., Okitani, A., Hayase, F., and Kato, H. (1986): Characterization of tryptophan derivatives from the reaction of $N^{\alpha}$-acetyl-tryptophan with carbonyl compounds. Agric. 
Biol. Chem., 50, 2315-2323.

16) Nielsen, H. K. (1984): Nutritional aspects of reactions between oxidizing lipid and protein. Thesis No. 865, University of Fribourg, Switzerland.

17) Nielsen, H. K., Löliger, J., and Hurrell, R. F. (1985): Reactions of proteins with oxidizing lipids. Br. J. Nutr., 53, 61-73.

18) Mauron, J. (1985): Influence of processing on protein quality. Bibl. Nutr. Dieta, 34, $56-81$.

19) Rothenbuhler, E., and Kinsella, J. E. (1986): Disulfide reduction and molecular dissociation improve the proteolysis of soy glycinin by pancreatin in vitro., J. Food Sci., 51, 1479-1482.

20) Mauron, J., Mottu, F., Bujard, E., and Egli, R. (1955): The availability of lysine, methionine and tryptophan in condensed milk and milk powder. In vitro digestion studies. Arch. Biochem. Biophys., 59, 433-451.

21) Oeste, R. E., Miller, R., Sjöström, H., and Noren, O. (1987): Effect of Maillard reaction products on protein digestion. Studies on pure compounds. J. Agric. Food Chem., 35, 938-942.

22) Mauron, J. (1975): Nutritional evaluation of processed proteins (in German). Dtsch. Lebensm. Rundsch., 71, 27-34.

23) Bujard, E., and Finot, P. A. (1978): Mesure de la disponibilité et du blocage de la lysine dans les laits industriels. Ann. Nutr. Alim., 32, 291-305.

24) Mauron, J. (1961): The concept of amino acid availability and its bearing on protein evaluation, in Meeting Protein Needs of Infants and Preschool Children. Publ. No. 843, Natl. Acad. of Sciences-Natl Res. Council, Washington D. C., pp. 37-51.

25) Finot, P. A., and Magnenat, E. (1981): Metabolic transit of early and advanced Maillard products, in Progress in Food and Nutrition Science, Vol. 5: Maillard Reactions in Food, ed. by Eriksson, C., Pergamon Press, Oxford, pp. 193-207.

26) Slump, P., Bos, K. D., and Verbeek, C. (1983): Methionine in oxidized proteins; analysis and bioavailability. Proceedings of the 2nd European Conference of Food Chemistry. Rome, pp. 323-328.

27) Ohara, I., Otsuka, S. I., Yugari, Y., and Ariyoshi, S. (1980): Comparison of the nutritive value of L, DL- and D-tryptophan in the rat and chick. J. Nutr., 110, 634-640.

28) Finot, P. A., Magnenat, E., Mottu, F., and Bujard, E. (1978): Disponibilité biologique et transit métabolique des acides aminés modifiés par les traitements technologiques. Ann. Nutr. Alim., 32, 325-338.

29) Kaufmann, W. (1984): Zum Einfluss unterschiedlicher technologischer Behandlung von Milch auf die Verdauungsvorgänge im Magen. VI Messungen von Aminosäure- und Harnstoffgehalten im Blut. Milchwissenschaft, 39(5), 281-284.

30) Meisel, H., and Hagemeister, H. (1987): Postprandiale Proteolyse von Casein and Sojaprotein. Milchwissenschaft, 42 (3), 153-157.

31) Harper, J. M., and Jansen, G. R. (1985): Production of nutritious precooked foods in developing countries by low-cost extrusion technology. Food Rev. Int., 1, 27-97.

32) de la Guerivière, J. F., Mercier, C., and Bandet, I. (1985): Incidences de la cuisson-extrusion sur certains paramètres nutritionnels de produits alimentaires notamment céréaliers. Cahiers Nutr. Diet, 20, 201-210.

33) Linko, P., Colonna, P., and Mercier, C. (1981): High temperature, short time extrusion cooking. Adv. Cereal Sci. Tech., 4, 145-235.

34) Björck, I., Asp. N. G., and Dahlqvist, A. (1984): Protein nutritional value of extrusion-cooked wheat flours. Food Chem., 15, 203-214. 